\title{
From Sustainability to Resilience: A Change of Wording or a Change in Thinking?
}

\begin{abstract}
During the past ten years or so, any application for a research grant had to contain the word "sustainability". Recently, however, sustainability has given way to "resilience". Why this change? It could be a change in research fashion, or the recently produced atmosphere of threat, especially in relation to cities.
\end{abstract}

Keywords: sustainability, resilience, resilience and sustainability.

\section{Od zrównoważonego rozwoju do wytrzymałości: zmiana nazewnictwa, czy zmiana w myśleniu?}

\begin{abstract}
Abstrakt
W ciągu ostatnich około dziesięciu lat wszystkie wnioski o granty badawcze musiały zawierać wyrażenie „zrównoważony rozwój”. W ostatnim jednak czasie „zrównoważony rozwój” ustąpił miejsca „wytrzymałości”. Skąd ta zmiana? Może być ona związana ze zmianą mody $\mathrm{w}$ badaniach naukowych lub powstałą ostatnio atmosferą zagrożenia, szczególnie $\mathrm{w}$ odniesieniu do miast.
\end{abstract}

Słowa kluczowe: zrównoważony rozwój, wytrzymałość, wytrzymałość i zrównoważony rozwój.

From its origin in ecology studies, sustainability came to be translated into practically every other domain of social life. We are now exploring sustainable equality together with sustainable waste management; sustainable relationships and sustainable cities. And most importantly, economic growth is to be sustainable, as well.

\footnotetext{
* University of Gothenburg, Sweden.
} 
In metallurgy, resilience is the ability of a material to absorb energy when it is deformed elastically and to release that energy upon unloading. But resilience is usually used metaphorically, and, like sustainability, resilience translates smoothly from one domain of life to another - even more easily, because resilience has a great many sources. It pleases even the Actor-Network theoreticians, because it applies to humans and nonhumans alike. During his presentation at the PARSE conference in Gothenburg, November 2015, Bruno Latour spoke practically only about the studies done by the Stockholm Resilience Centre. The Stockholm Resilience Centre is "an international centre of excellence for resilience and sustainability science", indicating the kinship between the two notions. "Since its launch in 2007, SRC has developed into a world-leading science centre for addressing the complex challenges facing humanity". On their webpage, resilience is defined as "the ability to deal with change and continue to develop" (https://www.stockholmresilience.org/research/resilience-dictionary.html). But whose ability is not specified.

The Stockholm Resilience Centre is a joint initiative of Stockholm University, the Stockholm Environment Institute and the Beijer International Institute of Ecological Economics at The Royal Swedish Academy of Sciences. The Centre is financed by the Foundation for Strategic Environmental Research, MISTRA, previously the major financier of sustainability research, which probably explains the addition of the word "sustainability", that was not there in 2013.

But why resilience? Resilience is a desirable trait of systems, because resilience "is a capability to recover" from crises, emergencies, and accidents, wrote organization scholars Karl Weick and Kathleen Sutcliffe in their 2001 bestseller, Managing Unexpected: Resilient Performance in an Age of Uncertainty. Their book went into its second edition in 2007. Weick and Sutcliffe referred to the notion of resilience as introduced by Aaron Wildavsky in his 1988 book, Searching for Safety. This notion was repeated in the entry "Risk and safety" to The Concise Encyclopedia of Economics, co-authored by Aaron Wildavsky's son, Adam Wildavsky, in 1993 - the year his father died. The Encyclopedia went into a second edition in 2007. Speak of an idea whose time has come... The Wildavskys ended their entry as follows: "A strategy of resilience [in contrast to strategy of anticipation], requires reliance on experience with adverse consequences once they occur in order to develop a capacity to learn from the harm and bounce back. Resilience, therefore, requires the accumulation of large amounts of generalizable resources-such as organizational capacity, knowledge, wealth, energy, and communication-that can be used to craft solutions to problems that the people involved did not know would occur. Thus, a strategy of resilience requires much less predictive capacity but much more growth, not only in wealth, but also in knowledge" (http://www.econlib.org/library/Enc/ RiskandSafety.html).

So while sustainability required prediction and planning, resilience requires mobilization of resources "just in case". 
Wildavsky (1988), and Weick and Sutcliffe (2007[2001]), wrote primarily about resilient organizations, but also about resilient performance, thereby alluding to the psychological concept of resilience. In psychology, and I quote, "resilience is the capacity to withstand stress and catastrophe. Psychologists have long recognized the capabilities of humans to adapt and overcome risk and adversity. Individuals and communities are able to rebuild their lives even after devastating tragedies" (http://www.cbttherapies.org.uk/2015/11/17/emotional-resilience-and-rebt/). Resilience is most commonly understood as a process, and not a trait of an individual. According to Wikipedia (https://en.wikipedia.org/wiki/Psychological_ resilience), studies on psychological resilience started in the 1970s, but their number has visibly increased with the boom of the last five years or so. It has even managed to earn a critique (Evans, Reid 2014), and even if the researchers treat it as a process and not a trait, it is still an individual process.

Perhaps most recent is the application of the notion of resilience to computer systems. According to one research paper, "Computer networking community defines [resilience] as the combination of trustworthiness (dependability, security, performability) and tolerance (survivability, disruption tolerance, and traffic tolerance)" (Trivedi, Kim, Ghosh 2009:74). This is certainly the widest definition of all.

So, why is resilience replacing sustainability, or at least relegating sustainability to second place? Perhaps it is simply a change in research fashion. As Gabriel Tarde (1962[1890]) explained one hundred and thirty years ago, people follow fashions, but then become tired, or bored with them, and look around for something new. Yes, but why resilience? And why now?

One explanation, relevant especially in the context of big cities, is the recently produced atmosphere of threat, no matter how much supported by facts. Cities are threatened by incipient terrorists (that is, immigrants), and therefore have to be resilient. Here, Wildavsky's definition fits very well: "resilience (...) requires reliance on experience with adverse consequences once they occur in order to develop a capacity to learn from the harm and bounce back" (http://www.econlib. org/library/Enc/RiskandSafety.html). Indeed, some cities did experience events with adverse consequences and now claim to have learned from them.

Another possible answer is the discovery that sustainability costs money. This observation coincided with, or was even caused by, the economic crisis of 20082010 - first in the global context of banking and finance, and then in the context of a European "malaise", as it has recently been called. What we need is a resilient Euro, a resilient European Union (once Brexit is over), but also resilient consumers, and resilient computer systems that can recover from zombie attacks and similar misadventures. It seems likely, therefore, that the next shift will be not from economy to ecology, as Bruno Latour (2004) hoped, but from ecology to economy. This may mean the economizing of ecological measures and - within the growing movement against Merkel's and Macron's austerity programmes - the elimination of the adjective "sustainable" from "sustainable growth". 
For the time being, however, at least in grant applications, the safest move is to combine both, as Stockholm Institute does: promise to study resilience AND sustainability!

\section{References}

Evans Brad, Reid Julian (2014) Resilient life: The art of living dangerously, Cambridge, Polity Press.

Latour Bruno (2004) Politics of nature. How to bring the sciences into democracy, transl. by C. Porter Cambridge, Harvard University Press.

Latour Bruno (2005) Reassembling the social, Oxford, Oxford University Press.

Tarde Gabriel (1962[1890]) The laws of imitation, New York, Henry Holt.

Trivedi Kishor S., Kim Dong Seong, Ghosh Rahul (2009) Resilience in computer systems and networks in: ICCAD '09 Proceedings of the 2009 International Conference on Computer-Aided Design, pp. 74-77.

Weick Karl E., Sutcliffe Kathleen M. (2007[2001]) Managing unexpected: Resilient performance in an age of uncertainty, San Francisco, Jossey-Bass.

Wildavsky Aaron (1988) Searching for safety, New York, Routledge.

\section{Online resources}

https://www.stockholmresilience.org/research/resilience-dictionary.html [accessed: 10.04.2019].

http://www.econlib.org/library/Enc/RiskandSafety.html [accessed: 10.04.2019].

http://en.wikipedia.org/wiki/Psychological_resilience [accessed: 10.04.2019].

http://www.cbttherapies.org.uk/2015/11/17/emotional-resilience-and-rebt/ [accessed: 26.04.2019]. 